\title{
PREVALENCE OF HYPERURICEMIA IN SUKKUR; PAKISTAN: A CROSS SECTIONAL SURVEY.
}

1. MBBS, FCPS

Associate Professor

Department of Medicine

Ghulam Muhammad Mahar

Medical Teaching Hospital

2. MBBS

Post Graduate

Department of Internal Medicine

Ghulam Muhammad Mahar

Medical Teaching Hospital

3. MBBS

Post Graduate

Department of Internal Medicine

Ghulam Muhammad Mahar

Medical Teaching Hospital

Correspondence Address:

Dr. Altaf Shaikh

Sheikh House, S Palace,

Near Hotel One Military Road, Sukkur.

draltafshaikh6464@gmail.com

Article received on:

12/09/2018

Accepted for publication:

16/01/2019

Received after proof reading:

$28 / 08 / 2019$

\begin{abstract}
Altaf Ahmed Shaikh1, Rajesh ${ }^{2}$, Anam Altaf ${ }^{3}$
ABSTRACT... Objectives: To find out the frequency uric acid levels in Pakistani general population. Study Design: Cross sectional study. Setting: Hira Medical Centre Sukkur. Period: July 12018 to July 31, 2018. Materials and Methods: The survey for was conducted in various hospitals and clinics all over Pakistan. 900 numbers of questionnaires were distributed of which 801 numbers responded. Those who agreed to be part of this study were asked. Uric acid levels were assessed by using UASure Blood Uric Acid Monitoring System. Those with greater than $6 \mathrm{mg} / \mathrm{dl}$ were classified as hyperuricemia according to American college of Rheumatology. Descriptive analysis was performed with SPSS software version 23. Frequency of patients with hyperuricemia was calculated. Stratification with respect to gender and age was calculated via cross tabulation. Results: Out of 135 patients, 102 (75.5\%) were male while $33(25.5 \%)$ were female with mean \pm SD age of $56.72 \pm 12.24$ years. The prevalence of hyperuricemia was $33.33 \%(n=45)$. Mean Uric acid levels were $6.12 \pm 1.68 \mathrm{mg} / \mathrm{dl} .31 .3 \%(n=32)$ male and $39.3 \%$ $(n=13)$ females were hyperuricemic. Conclusion: Prevalence of Hyperuricemia in Sukkur is alarming and efforts should be made to aware patients about the consequences of.
\end{abstract}

Key words: $\quad$ Gout, Hyperuricemia, Prevalence, Pakistan, Uric Acid.

Article Citation: Shaikh AA, Rajesh, Altaf A. Prevalence of hyperuricemia in Sukkur; Pakistan: a cross sectional survey. Professional Med J 2019; 26(9):15671569. DOI: 10.29309/TPMJ/2019.26.09.4027

\section{INTRODUCTION}

Hyperuricemia still has not gotten the attention in developing country and there is very meagre data available on hyperuricemia from developing country. ${ }^{1}$ Break-down of Purine nucleotide, both endogenous that is break down of nucleic acid and exogenous taken from meal, results in uric acid..$^{2,3,4} \mathrm{~A}$ uric acid level of more than $6.8 \mathrm{mg} / \mathrm{dl}$ at normal body temperature of $37^{\circ} \mathrm{C}$ and neutral $\mathrm{pH}$ is considered as Hyperuricemia. ${ }^{5}$ Hyperuricemia have been identified as a risk factor for diseases such as Ischemic heart disease, Sroke, Peripheral artheriopathy, diabetes and renal failure. High serum uric acid levels have now been confirmed as a prognostic predictor of survival in heart failure. Even if risk factors such as metabolic syndrome and hyperuricemic diuretics are removed, the risk remains for above mentioned disease with elevated uric acid, making hyperuricemia an independent risk factor. ${ }^{6-10}$

A local study published in 2011 showed uric acid levels are high in older people in Gadap, a small town of Karachi. ${ }^{11}$ Another study showed a mean uric acid level of $6.11 \pm 1.7 \mathrm{mg} / \mathrm{dll}^{12}$ There is very little data available on prevalence of hyperuricemia in Pakistan. Search of Pakmedinet. com with keyword of hyperuricemia and uric acid showed less than 15 studies. Compared to it, Diabetes showed 2140 studies and hypertension showed 1543 studies.

The purpose of my study is to determine the prevalence of hyperuricemic patient in Sukkur so a regional effort can be made to aware people about hyperuricemia and its consequences in Pakistan.

\section{PATIENTS AND METHODS}

This cross sectional study was conducted in Hira Medical Centre Sukkur. From July 12018 to July 31,2018 , total of 135 that fulfilled the inclusion criteria were included in the study after taking informed consent. Those who agreed to be part 
of this study were asked. Uric acid levels were assessed by using UASure Blood Uric Acid Monitoring System. Those with greater than $6.8 \mathrm{mg} / \mathrm{dl}$ were classified as hyperuricemia. ${ }^{5}$ Descriptive analysis was performed with SPSS software version 23. Frequency of patients with hyperuricemia was calculated. Stratification with respect to gender and age was calculated via cross tabulation.

\section{RESULTS}

Out of 135 patients, $102(75.5 \%)$ were male while $33(25.5 \%)$ were female with mean \pm SD age of $56.72 \pm 12.24$ years (Table-I). The prevalence of hyperuricemia was $33.33 \%(n=45)$ (Table-II). Mean Uric acid levels were $6.12 \pm 1.68 \mathrm{mg} / \mathrm{dl}$. $31.3 \%(n=32)$ male and $39.3 \%(n=13)$ females were hyperuricemic (Table-III).

\begin{tabular}{|l|c|c|}
\hline \multicolumn{1}{|c|}{} & Mean & Std. Deviation \\
\hline Age & 56.72 & 12.24 \\
\hline Uric Acid & & \\
\hline Total & 6.12 & 1.68 \\
\hline Male & 6.28 & 1.70 \\
\hline Female & 5.92 & 1.58 \\
\hline
\end{tabular}

\begin{tabular}{|l|c|}
\hline \multicolumn{1}{|c|}{ Uric Acid Level } & N (\%) \\
\hline Normouric & $90(66.6 \%)$ \\
\hline Hyperuricemic & $45(33.3 \%)$ \\
\hline \multicolumn{2}{|c|}{ Table-II. Prevalence of hyperuricemia } \\
\hline
\end{tabular}

\begin{tabular}{|l|c|c|}
\hline Gender & $\begin{array}{c}\text { Normouricemia } \mathbf{n} \\
\text { (\%) }\end{array}$ & $\begin{array}{c}\text { Hyperuricemia } \mathbf{n} \\
\text { (\%) }\end{array}$ \\
\hline Male & $70(68.7 \%)$ & $32(31.3 \%)$ \\
\hline Female & $19(57.6 \%)$ & $14(42.4 \%)$ \\
\hline
\end{tabular}

Table-III. Prevalence of hyperuricemia according to gender

\section{DISCUSSION}

In this survey, conducted in Sukkur, Prevalence of hyperuricemia was substantial. $33.3 \%$. This study shall be beneficial to add to very limited data available on prevalence of hyperuricemia. The prevalence of hyperuricemia in Sukkur is comparable to national prevalence of hyperuricemia which was stated as $39 \%$ in study published in 2017 by Qudwai W. ${ }^{12}$ Qudwai stated that mean uric acid level is $6.11 \pm 1.7 \mathrm{mg} / \mathrm{dl}$. Mean uric acid level in males was $6.19 \pm 1.65 \mathrm{mg} / \mathrm{dl}$ and in females it was recorded as $6.04 \pm 1.75 \mathrm{mg} / \mathrm{dl} .{ }^{12}$ Mean uric acid level in our study was $6.12 \pm 1.68$ and that of male was $6.28 \pm 1.70$ and in female it was $5.92 \pm 1.58$. Qudwai in his study established hyperuricemia was more common in females in Pakistan (49.7\%) which was also the case in our study which had prevalence of hyperuricemia in female $(42.4 \%)$ compared to make of $(31.3 \%)$. Asia country has shown increase trend for prevalence of hyperuricemia with China showing prevalence as high as $25 \%$, Taiwan as high as $52 \%$ and Indonesia with $18 \% .{ }^{13}$ Our neighbouring country India has a prevalence of $44.6 \%$ as per study conducted in $2012 .{ }^{14}$

This trend that indicates high prevalence of hyperuricemia can be attributed to increasing age which means increase number of years with chronic diseases like hypertension and diabetes. ${ }^{15}$ Other reasons for this increase prevalence of hyperuricemia in developing country such as India and Pakistan may be recent changes in diet, a sedentary lifestyle, antihypertensive medications mainly diuretics. ${ }^{16,17}$

\section{CONCLUSION}

The prevalence of hyperuricemia is high in Sukur and it is very necessary to give equal attention and awareness to hyperuricemia as to the chronic diseases.

Copyright $(16$ Jan, 2019.

\section{REFERENCES}

1. Conen D, Wietlisbach V, Bovet P, Shamlaye C, Riesen W, Paccaud F, Burnier M. Prevalence of hyperuricemia and relation of serum uric acid with cardiovascular risk factors in a developing country. BMC public health. $2004 \mathrm{Dec} ; 4(1): 9$.

2. Richette P, Bardin T. Gout. Lancet. 2010; 375(9711):31828. [PubMed].

3. Choi HK, Mount DB, Reginato AM. Pathogenesis of gout. Ann Intern Med. 2005; 143:499-516. [PubMed].

4. Johnson RJ, Rideout BA. Uric acid and diet - insights into the epidemic of cardiovascular disease. $\mathrm{N}$ Engl J Med. 2004; 350:1071-4. 
5. Eggebeen AT. Gout: An update. Am Fam Physician. 2007; 76(6):801-8.

6. Abbott RD, Brand FN, Kannel WB, Castelli WP. Gout and coronary heart disease: The framingham study. J Clin Epidemiol. 1988; 41:237-42.

7. Choi HK, Curhan G. Independent impact of gout on mortality and risk for coronary heart disease. Circulation. 2007; 116:894-900.

8. Choi HK, Ford ES, Li C, Curhan G. Prevalence of the metabolic syndrome in patients with gout: The third national health and nutrition examination survey. Arthritis Rheum. 2007; 57:109-15.

9. Krishnan E, Baker JF, Furst DE, Schumacher HR. Gout and the risk of acute myocardial infarction. Arthritis Rheum. 2006; 54:2688-96.

10. Krishnan E, Svendsen K, Neaton JD, Grandits G, Kuller LH MRFIT Research Group. Long-term cardiovascular mortality among middle-aged men with gout. Arch Intern Med. 2008; 168:1104-10.

11. Akram M. Prevalence of gout in gadap town, Karachi. Afr J Bio Tec. 2011; 10 (40); 7893-95.
12. Qidwai W. Frequency of uric acid levels, symptomatic and asymptomatic hyperuricemia among the Pakistani population. W Fam Med J. 2017; 15(7):5255.

13. Smith E, March L. Global Prevalence of Hyperuricemia: A Systematic Review of PopulationBased Epidemiological Studies: Abstract Number: 2236. Arthritis \& Rheumatology. 2015 Oct 1;67:26902.

14. Remedios C, Shah M, Bhasker AG, Lakdawala M. Hyperuricemia: A reality in the Indian obese. Obes Surg. 2012; 22:945-948.

15. Gauri Billa et al., Pancreat Disord Ther 2017, 7:4(Suppl) DOI: 10.4172/2165-7092-C1-008.

16. Saag KG, Choi H. Epidemiology, risk factors, and lifestyle modifications for gout. Arthritis Research \& Therapy. 2006; 8(Suppl 1):S2. doi:10.1186/ar1907.

17. Conen D, Wietlisbach V, Bovet $P$, et al. Prevalence of hyperuricemia and relation of serum uric acid with cardiovascular risk factors in a developing country. BMC Public Health. 2004; 4:9. doi:10.1186/1471-2458-4-9.

\begin{tabular}{|c|c|c|c|}
\hline \multicolumn{4}{|c|}{ AUTHORSHIP AND CONTRIBUTION DECLARATION } \\
\hline Sr. \# & Author-s Full Name & Contribution to the paper & Author $=$ s Signature \\
\hline 1 & $\begin{array}{l}\text { Altaf Ahmed Shaikh } \\
\text { Rajesh }\end{array}$ & $\begin{array}{l}\text { Conception, Data collection and } \\
\text { manuscript writing. } \\
\text { Data collection and analysis. }\end{array}$ & \\
\hline 3 & Anam Altaf & Data collection and analysis. & \\
\hline
\end{tabular}

